\title{
Cluster analysis in severe emphysema subjects using phenotype and genotype data: an exploratory investigation
}

\author{
Michael H Cho ${ }^{1,2^{*}}$, George R Washko², Thomas J Hoffmann ${ }^{3}$, Gerard J Criner ${ }^{4}$, Eric A Hoffman ${ }^{5}$, \\ Fernando J Martinez ${ }^{6}$, Nan Laird ${ }^{3}$, John J Reilly ${ }^{7}$, Edwin K Silverman ${ }^{1,2}$
}

\begin{abstract}
Background: Numerous studies have demonstrated associations between genetic markers and COPD, but results have been inconsistent. One reason may be heterogeneity in disease definition. Unsupervised learning approaches may assist in understanding disease heterogeneity.

Methods: We selected 31 phenotypic variables and 12 SNPs from five candidate genes in 308 subjects in the National Emphysema Treatment Trial (NETT) Genetics Ancillary Study cohort. We used factor analysis to select a subset of phenotypic variables, and then used cluster analysis to identify subtypes of severe emphysema. We examined the phenotypic and genotypic characteristics of each cluster.

Results: We identified six factors accounting for $75 \%$ of the shared variability among our initial phenotypic variables. We selected four phenotypic variables from these factors for cluster analysis: 1) post-bronchodilator FEV 1 percent predicted, 2) percent bronchodilator responsiveness, and quantitative CT measurements of 3) apical emphysema and 4) airway wall thickness. K-means cluster analysis revealed four clusters, though separation between clusters was modest: 1) emphysema predominant, 2) bronchodilator responsive, with higher $\mathrm{FEV}_{1}$; 3 ) discordant, with a lower $\mathrm{FEV}_{1}$ despite less severe emphysema and lower airway wall thickness, and 4) airway predominant. Of the genotypes examined, membership in cluster 1 (emphysema-predominant) was associated with TGFB1 SNP rs1800470.
\end{abstract}

Conclusions: Cluster analysis may identify meaningful disease subtypes and/or groups of related phenotypic variables even in a highly selected group of severe emphysema subjects, and may be useful for genetic association studies.

\section{Background}

Chronic Obstructive Pulmonary Disease (COPD) is defined by the Global Initiative for Chronic Obstructive Lung Disease (GOLD) as airflow limitation that is not fully reversible[1]. This deliberately broad and simple definition based on reduced expiratory airflow has been useful in leading to increased awareness and understanding of the disease[2]. However, substantial heterogeneity within this definition exists[3,4]. Moving beyond spirometry and evaluating other variables is critical to understanding differences in patients with COPD, to gain mechanistic insights into the disease, to identify

\footnotetext{
* Correspondence: remhc@channing.harvard.edu

'Channing Laboratory, Brigham \& Women's Hospital, Boston, MA, USA
}

those at highest risk of specific outcomes, and to personalize therapy [4-7].

Substantial evidence indicates that genetic variation contributes to differences in COPD susceptibility; however, replication of genetic associations in COPD - and in many other complex diseases - has generally been poor[8]. Disease heterogeneity is likely an important factor for these inconsistent findings[9,10]. Several attempts to overcome heterogeneity have been used, including using classic subtypes of chronic bronchitis or emphysema[11], defining subtypes based on a pathophysiologic characteristic (such as rapid or slow decline in lung function[12]), or assessing phenotypic characteristics by chest CT scans[13]. 
Statistical learning techniques offer an opportunity to extract novel patterns and trends from phenotypic data [14], and thus identify COPD subtypes without using a priori expectations about disease characteristics[15-20]. To our knowledge, these strategies have not been applied in a group with severe emphysema, nor have studies used these subtypes in a genetic association study. We hypothesized that cluster analysis would identify distinct subtypes of COPD subjects, and that variants in COPD candidate genes would be associated with these subtypes.

\section{Methods}

Details of subject recruitment and phenotyping in the National Emphysema Treatment Trial (NETT) have been reported previously[21]. Briefly, NETT participants had physician-diagnosed COPD, $\mathrm{FEV}_{1} \leq 45 \%$ predicted, evidence of hyperinflation on pulmonary function testing, and bilateral emphysema on chest CT scan. Enrollment in the NETT Genetics Ancillary Study began after the initiation of the clinical trial, and thus only a subset of the original cohort had DNA available for genotyping. The characteristics of NETT subjects included and excluded from this analysis are shown in Additional File 1, Table S1. Participants gave written informed consent. The appropriate institutional review boards approved all studies. Self-identified white subjects in the NETT Genetics Ancillary Study with complete CT phenotypic data (emphysema and airway wall quantitative measures) were included in the analysis.

We selected a set of $31 \mathrm{CT}$, lung function, and other key phenotypic variables, based on clinical relevance, inclusion in previous genetic association studies, and complete data, to avoid subject drop-out (Table 1). Measurements of the phenotypic variables have been previously described[21-25]. 12 SNPs from 5 genes were chosen on the basis of available genotyping and prior associations with COPD (Table 2), and included genes involved in xenobiotic metabolism (EPHX1 and GSTP1) and surfactant homeostasis (SFTPB), as well as two genes identified in part through linkage studies: TGFB1, a cytokine growth factor, and SERPINE2, a thrombin and urokinase inhibitor. A limited number of SNPs were selected in order to limit multiple statistical testing in this relatively small study population[26]. For the gene SERPINE2[27,28], in which numerous associations have been described, we chose SNPs tagging associations found in at least two populations, using a $\mathrm{r}^{2}$ cutoff of $>0.8$ in Tagger [29] as implemented in Haploview 4.1 [30].

We used factor analysis as a guide to determine which COPD phenotypic variables to include in our clustering analysis[31]. Factor analysis is a data reduction technique related to principal component analysis, where shared variability in several observed variables is explained in terms of fewer unobserved variables, called factors. The strength of the relationship between the observed variables and factors can be measured by factor loadings. We used factor analysis in two ways: first, to select variables which represent greater amounts of shared variability; and second, among these variables, to select one representative measurement using a high factor loading to avoid over-weighting correlated COPD characteristics, which could bias a cluster analysis.

The goal of cluster analysis is to assign subjects to groups, where subjects in the same cluster are more similar to each other than they are to subjects in other groups[14]. Similarity is generally defined using a measurement of distance, calculated using the difference between measurements. As numerous clustering methods exist, we evaluated the performance of several clustering algorithms. We chose the best performing clustering technique and cluster number using the silhouette width, a measure of how close each point in one cluster is to points in neighboring clusters. We then examined each variable for differences among the clusters.

\section{Results}

A total of 308 subjects from the NETT Genetics Ancillary Study were included in the analysis. Phenotypic variables selected for inclusion in the factor analysis are shown in Table 1. SNPs included for analysis, along with their minor allele frequencies and previous genetic association studies in COPD (both in the NETT cohort and others) are listed in Table 2. Six factors accounted for $75 \%$ of the common variance. Eigenvalues for these factors ranged from 1.7 to 4.9; two additional factors (not shown) had eigenvalues $>1.0$. The results of the factor analysis are shown in Table 1. These factors were interpreted as: 1) spirometry (containing pre- and post-bronchodilator $\mathrm{FEV}_{1}$ and FVC percent predicted); 2) airway wall thickness (wall thickness, derived square root wall area of a $10 \mathrm{~mm}$ internal perimeter airway and derived wall area percent of a $10 \mathrm{~mm}$ airway); 3) $\mathrm{FEV}_{1} / \mathrm{FVC}$ ratio; 4) quantitative emphysema severity and distribution (divided into equal thirds by absolute lung height from apex to base), using a cutoff of -950 Hounsfield units; 5) bronchodilator responsiveness; and 6) maximum work and gender. The following variables were chosen as representative based on relatively high factor loadings, accounting for a greater proportion of shared variability: post-bronchodilator $\mathrm{FEV}_{1}$ percent predicted (for factors 1 and 3), airway wall thickness (factor 2), apical emphysema (factor 4), and bronchodilator responsiveness (factor 5 ).

Based on measures of silhouette width, the k-means clustering algorithm using four clusters was found to be optimal for this dataset. This optimal value was low 
Table 1 Factor analysis.

\begin{tabular}{|c|c|c|c|c|c|c|}
\hline & Factor 1 & Factor 2 & Factor 3 & Factor 4 & Factor 5 & Factor 6 \\
\hline Age, years & 0.226 & & & & & \\
\hline $\mathrm{BMl}, \mathrm{kg} / \mathrm{m} 2$ & & 0.272 & & -0.123 & 0.117 & \\
\hline Gender (\% male) & 0.181 & -0.119 & 0.153 & & & -0.712 \\
\hline Pack-years of smoking & & & & & & 0.187 \\
\hline Age started smoking & & & & & & -0.237 \\
\hline Age quit smoking & 0.146 & 0.14 & & & & -0.11 \\
\hline Pre-bronchodilator $\mathrm{FEV}_{1}, \%$ predicted & 0.852 & & 0.466 & & -0.181 & 0.1 \\
\hline Pre-bronchodilator FVC, \% predicted & 0.903 & & -0.247 & & & 0.154 \\
\hline Post-bronchodilator $\mathrm{FEV}_{1}, \%$ predicted & 0.853 & & 0.461 & & 0.209 & \\
\hline Post-bronchodilator FVC, \% predicted & 0.899 & & -0.301 & & 0.172 & 0.193 \\
\hline Bronchodilator response, $\%$ of baseline $\mathrm{FEV}_{1}$ & & & & & 0.979 & \\
\hline Bronchodilator response, absolute change in $\mathrm{FEV}_{1}, \mathrm{~L}$ & 0.163 & & & & 0.943 & 0.183 \\
\hline $\mathrm{FEV}_{1} / \mathrm{FVC}$ ratio, post-bronchodilator & 0.104 & & 0.961 & & & -0.134 \\
\hline $\mathrm{FEV}_{1} / \mathrm{FVC}$ ratio, pre-bronchodilator & & & 0.902 & & -0.106 & \\
\hline Total lung capacity, \% predicted & & -0.165 & -0.227 & 0.151 & & \\
\hline Residual volume, \% predicted & -0.506 & & -0.145 & 0.199 & -0.132 & \\
\hline Diffusion capacity, \% predicted & 0.169 & & 0.219 & -0.253 & & 0.286 \\
\hline Total fraction emphysema at $-950 \mathrm{HU}$ & & -0.214 & -0.178 & 0.822 & & \\
\hline Difference between apical and basal emphysema at $-950 \mathrm{HU}$ & & & & 0.846 & & -0.108 \\
\hline Apical fraction emphysema at $-950 \mathrm{HU}$ & & -0.141 & & 0.981 & & \\
\hline Airway wall thickness, mm & & 0.96 & & & & \\
\hline Airway wall area, \% & & 0.94 & & -0.114 & & \\
\hline Square root wall area, $\mathrm{cm}$ & & 0.882 & & & & \\
\hline 6 minute walk distance, $\mathrm{ft}$ & 0.175 & -0.105 & & & 0.104 & 0.566 \\
\hline Maximum work, watts & 0.174 & & 0.135 & -0.1 & 0.164 & 0.791 \\
\hline UCSD Shortness of Breath Questionnaire & -0.227 & & & & & -0.307 \\
\hline Arterial pH & 0.212 & & 0.107 & 0.146 & & \\
\hline $\mathrm{PaO}_{2}, \mathrm{mmHg}$ & 0.2 & & 0.205 & & & 0.256 \\
\hline $\mathrm{PaCO}_{2}, \mathrm{mmHg}$ & -0.293 & & -0.345 & -0.104 & & -0.166 \\
\hline Exacerbations in year prior to randomization & & -0.123 & & & & -0.113 \\
\hline Exacerbations/year (over 3.3 years) & & -0.107 & -0.204 & & & 0.152 \\
\hline
\end{tabular}

Six factors were identified accounting for $75 \%$ of the common variance. Higher factor loadings indicate higher correlations of the variable with that factor. Loadings $\geq|0.1|$ are shown.

( $\sim 0.2)$ consistent with modest separation of the clusters. A plot of the clusters with each pair of phenotypic variables is shown in Additional file 1, Figure S1. Differences between the selected phenotypic variables by cluster are shown in Table 3. As expected, all selected phenotypic variables selected for use in cluster analysis were significantly different between clusters $\left(\mathrm{P}<10^{-3}\right)$. Cluster 1 had the greatest degree of emphysema and the least airway wall thickness, as well as a lower $\mathrm{FEV}_{1}$. Conversely, cluster 4 had the highest airway wall thickness and the least emphysema, and also had lower bronchodilator responsiveness and $\mathrm{FEV}_{1}$. Cluster 2 was a milder subgroup, with the highest $\mathrm{FEV}_{1}$ and bronchodilator responsiveness, as well as less emphysema.
Cluster 3 also had less emphysema and in addition, less airway wall thickness; however, in contrast to cluster 2 , this cluster was more severely affected with the lowest $\mathrm{FEV}_{1}$ and bronchodilator responsiveness.

Additional phenotypic variables, not included in the cluster analysis, were then examined to determine other characteristics of these clusters. Significant differences among the groups were found for several characteristics (Table 3). Cluster 1, the emphysema predominant cluster, had a lower BMI, fewer pack-years of smoking, higher total lung capacity, and lower diffusing capacity, along with a lower six minute walk distance and maximum work. Consistent with the radiographic clustering and the factor loadings, CT emphysema severity and apical-basal 
Table 2 Single nucleotide polymorphisms (SNPs).

\begin{tabular}{|c|c|c|c|c|c|}
\hline $\begin{array}{l}\text { Gene } \\
\text { Symbol }\end{array}$ & SNP & $\begin{array}{l}\text { Major/ } \\
\text { Minor } \\
\text { Allele }\end{array}$ & $\begin{array}{l}\text { Minor } \\
\text { Allele } \\
\text { Frequency }\end{array}$ & Association in NETT (Effect of Variant Genotype) & Other Reported COPD Association(s) \\
\hline \multirow[t]{2}{*}{ EPHX1 } & $\begin{array}{l}\text { rs1051740 } \\
\text { (Tyr113His) }\end{array}$ & T/C & 0.31 & Less maximum work[42] & $\begin{array}{l}\text { Associations with discordant directions; } \\
\text { meta-analysis with a protective effect of } \\
\text { the variant allele[55] }\end{array}$ \\
\hline & $\begin{array}{l}\text { rs2234922 } \\
\text { (His139Arg) }\end{array}$ & $A / G$ & 0.19 & $\begin{array}{l}\text { Decreased risk of COPD [9]; Lesser degree of apical } \\
\text { minus basilar emphysema [22]; increased DLCO[42], less } \\
\text { maximum work after LVRS[56] }\end{array}$ & $\begin{array}{l}\text { Wild type with variant type rs } 1051740, \\
\text { associated with lung function decline } \\
\text { [12] }\end{array}$ \\
\hline GSTP1 & $\begin{array}{l}\text { rs1695 (aka } \\
\text { rs947894) }\end{array}$ & $A / G$ & 0.36 & $\begin{array}{l}\text { Lesser degree of apical and apical minus basilar } \\
\text { emphysema [22] }\end{array}$ & $\begin{array}{l}\text { Associations with discordant directions } \\
\text { [57] }\end{array}$ \\
\hline \multirow[t]{3}{*}{ SERPINE2 } & rs6734100 & $C / G$ & 0.15 & & $\begin{array}{l}\text { Case-control and family-based; variant } \\
\text { less common in cases[28] }\end{array}$ \\
\hline & rs6747096 & $A / G$ & 0.19 & Protection from COPD [27] & \\
\hline & rs975278 & $\mathrm{C} / \mathrm{T}$ & 0.20 & Decreased apical emphysema [22] & Decreased risk of COPD [28] \\
\hline \multirow[t]{4}{*}{ SFTPB } & $\begin{array}{l}\text { rs1130866 } \\
\text { (Thr131lle) }\end{array}$ & $\mathrm{A} / \mathrm{G}$ & 0.46 & $\begin{array}{l}\text { Associated with COPD, in the presence of a gene-by- } \\
\text { environment interaction[9]; fewer exacerbations[23] }\end{array}$ & Associated with COPD $[9,58]$ \\
\hline & rs2118177 & $\mathrm{T} / \mathrm{C}$ & 0.35 & Fewer exacerbations[23] & \\
\hline & rs2304566 & $\mathrm{T} / \mathrm{C}$ & 0.25 & Fewer exacerbations[23] & \\
\hline & rs3024791 & $\mathrm{C} / \mathrm{T}$ & 0.16 & Fewer exacerbations[23] & \\
\hline \multirow[t]{2}{*}{ TGFB1 } & $\begin{array}{l}\text { rs1800470 (aka } \\
\text { rs1982073) } \\
\text { (Leu10Pro) }\end{array}$ & $\mathrm{A} / \mathrm{G}$ & 0.39 & $\begin{array}{l}\text { Decreased risk of COPD [59]; lower } \mathrm{FEV}_{1} \text { within } \\
\text { emphysema subjects[48]; increased apical emphysema } \\
\text { [22]; decreased airway wall thickness (unpublished } \\
\text { observations) }\end{array}$ & Decreased risk of COPD $[60,61]$ \\
\hline & rs1800469 & $\mathrm{G} / \mathrm{A}$ & 0.30 & $\begin{array}{l}\text { Decreased risk of COPD[59]; lower } \mathrm{FEV}_{1} \text { within } \\
\text { emphysema subjects[48]; greater dyspnea symptoms } \\
\text { [42]; increased apical emphysema[22] }\end{array}$ & \\
\hline
\end{tabular}

Twelve SNPs from nine candidate genes were chosen based on available genotyping and previous associations.

emphysema difference (defined as absolute percent emphysema in the upper lung region minus the lower lung region) were more severe, while airway wall area and square root of wall area were lower. Conversely, cluster 4, the airway predominant cluster, had a higher BMI, lower total lung capacity, and less severe emphysema and higher airway wall measurements, with a lower $\mathrm{PaO}_{2}$ and lower six minute walk distance. Cluster 2, the milder severity, bronchodilator responsive subtype, had a higher BMI, greater $\mathrm{FVC}$ and $\mathrm{DL}_{\mathrm{CO}}$, a lower $\mathrm{PaCO}_{2}$, higher six minute walk distance and maximum work, fewer symptoms of dyspnea, and fewer exacerbations, despite being of slightly older age. Cluster 3, with a lower $\mathrm{FEV}_{1}$ despite less severe radiographic emphysema and airway wall thickness than the other clusters, had more dyspnea and a higher $\mathrm{PaCO}_{2}$, with slightly younger age.

To determine whether specific SNPs were associated with cluster membership, we tested genotypes for each of the 12 candidate gene SNPs with cluster membership. A chi-squared $P$ value of 0.034 was seen for a SNP in TGFB1, rs1800470; no other $\mathrm{P}$ values were nominally $(<0.05)$ significant. In pairwise testing using an additive model of each cluster versus all other clusters, this SNP was associated with membership in cluster 1 $(\mathrm{P}=0.002)$.
Further details on study methods and additional results are available in Additional File 1, including plots of correlations and cluster separation in two-dimensional space (Additional file 1, Figures S1 and S3).

\section{Discussion}

Despite the description of COPD subtypes more than 40 years ago[32] and substantial progress since then in understanding COPD-related phenotypes[33,34], only a few attempts have been made to use statistical methods to define novel COPD subtypes[15,16]. Using a large, well-characterized set of subjects with severe emphysema, we demonstrate the potential utility of using statistical learning methods to find relationships among phenotypic and genotypic characteristics to elucidate disease heterogeneity.

Several methods have attempted to address issues of disease heterogeneity in obstructive airway diseases. Statistical learning techniques such as factor analysis have been used to reveal novel insights into characteristics such as dyspnea or inflammation in COPD[20,35-37]. Cluster analysis has confirmed classic chronic bronchitis and emphysema subtypes[15] or illustrated overlap of characteristics of COPD and asthma[16], and a combination of factor analysis and cluster analysis has defined 
Table 3 Baseline Phenotypic Characteristics and Results of Cluster Analysis.

\begin{tabular}{|c|c|c|c|c|c|c|}
\hline & \multirow[t]{2}{*}{ Cohort } & \multirow[t]{2}{*}{ Groupwise Test } & \multicolumn{4}{|c|}{ Cluster } \\
\hline & & & 1 & 2 & 3 & 4 \\
\hline $\mathrm{N}$ & 308 & & 66 & 102 & 88 & 52 \\
\hline \multicolumn{7}{|l|}{ Phenotypic Variables } \\
\hline Post-bronchodilator $\mathrm{FEV}_{1}, \%$ predicted & $28.3(7.33)$ & $2.60 \times 10^{-28}$ & $26.5^{*}$ & $34.3^{* *}$ & $23.9^{* *}$ & $26.2^{*}$ \\
\hline Bronchodilator response, $\%$ of baseline $\mathrm{FEV}_{1}$ & $13.6(0.12)$ & $5.10 \times 10^{-19}$ & 13.4 & $21.5^{* *}$ & $6.6^{* *}$ & $10.5^{*}$ \\
\hline Apical fraction emphysema at $-950 \mathrm{HU}^{\dagger}$ & $0.21(0-0.72)$ & $9.60 \times 10^{-30}$ & $0.47^{* *}$ & $0.17^{* *}$ & $0.16^{* *}$ & $0.15^{*}$ \\
\hline Airway wall thickness, mm & $1.53(0.25)$ & $5.10 \times 10^{-54}$ & $1.36^{* *}$ & 1.50 & $1.45^{* *}$ & $1.93^{* *}$ \\
\hline Age (years) & $67.4(6.08)$ & 0.023 & 66.5 & $68.6^{*}$ & $66.3^{*}$ & 68.2 \\
\hline $\mathrm{BMI}\left(\mathrm{kg} / \mathrm{m}^{2}\right)$ & $25.1(3.45)$ & 0.0001 & $23.7^{* *}$ & $25.7^{*}$ & 24.7 & $26.1^{*}$ \\
\hline Gender (\% male) & 64 & 0.37 & 56 & 64 & 69 & 67 \\
\hline Pack-years of smoking & $67.4(30.4)$ & 0.13 & $60.08^{* *}$ & 68.57 & 68.47 & 72.73 \\
\hline Age started smoking & 16.4 (3.58) & 0.37 & 16.74 & 16.60 & 15.85 & 16.63 \\
\hline Age quit smoking & $57.7(7.58)$ & 0.12 & 56.72 & 58.89 & 56.68 & 58.61 \\
\hline Pre-bronchodilator $\mathrm{FEV}_{1} \%$ predicted & $25.0(6.55)$ & $5.80 \times 10^{-11}$ & $23.48^{*}$ & $28.57^{* *}$ & $22.6^{* *}$ & 23.89 \\
\hline Pre-bronchodilator FVC \% predicted & $61.3(15.4)$ & $4.10 \times 10^{-7}$ & 59.0 & $68.2^{* *}$ & $57.3^{* *}$ & 57.5 \\
\hline Post-bronchodilator FVC \% predicted & $69.6(15.7)$ & $6.70 \times 10^{-14}$ & 67.5 & $79.1^{* *}$ & $62.9^{* *}$ & $65.2^{*}$ \\
\hline Bronchodilator response, absolute change in $\mathrm{FEV}_{1}, \mathrm{~L}$ & $0.09(0.09)$ & $1.90 \times 10^{-28}$ & 0.08 & $0.16^{* *}$ & $0.04^{* *}$ & $0.07^{* *}$ \\
\hline FEV $1 / F V C$ ratio (pre-bronchodilator) & $0.32(0.06)$ & 0.13 & 0.32 & 0.33 & 0.31 & 0.33 \\
\hline $\mathrm{FEV}_{1} / \mathrm{FVC}$ ratio (post-bronchodilator) & $0.32(0.06)$ & $2.10 \times 10^{-5}$ & 0.31 & $0.34^{* *}$ & $0.30^{* *}$ & 0.31 \\
\hline Total lung capacity, \%predicted & $128(15.3)$ & $3.00 \times 10^{-4}$ & $132.7^{* *}$ & 126.3 & 129.4 & $121.2^{* *}$ \\
\hline Residual volume, \% predicted & $216(47.4)$ & $1.20 \times 10^{-08}$ & $235.3^{* *}$ & $195.8^{* *}$ & $229.3^{* *}$ & 208.9 \\
\hline Diffusion capacity, \% predicted & $30(10.1)$ & $4.60 \times 10^{-6}$ & $25.2^{* *}$ & $33.1^{* *}$ & 29.0 & 31.7 \\
\hline Total fraction emphysema at $-950 \mathrm{HU}^{+}$ & $0.15(0-0.50)$ & $3.40 \times 10^{-25}$ & $0.31^{* *}$ & $0.13^{* *}$ & $0.12^{* *}$ & $0.11^{* *}$ \\
\hline Difference between fraction apical and basal emphysema at $-950 \mathrm{HU}^{+}$ & $0.12(-0.33-0.64)$ & $2.80 \times 10^{-22}$ & $0.37^{* *}$ & $0.08^{* *}$ & $0.06^{* *}$ & 0.08 \\
\hline Airway wall area, $\%$ & $73.3(3.96)$ & $9.90 \times 10^{-39}$ & $70.4^{* *}$ & 73.2 & $72.4^{* *}$ & $78.7^{* *}$ \\
\hline Square root airway wall area, $\mathrm{cm}$ & $4.6(0.50)$ & $2.10 \times 10^{-32}$ & $4.3^{* *}$ & 4.6 & $4.5^{* *}$ & $5.3^{* *}$ \\
\hline 6 minute walk distance $(\mathrm{ft})$ & $1265(318)$ & $1.90 \times 10^{-5}$ & $1192.2^{*}$ & $1382.1^{* *}$ & 1247.2 & $1155.7^{*}$ \\
\hline Maximum work (watts) & $43.8(22.3)$ & $5.20 \times 10^{-7}$ & $35.5^{* *}$ & $53.4^{* *}$ & 40.9 & 40.3 \\
\hline UCSD Shortness of Breath Questionnaire Score & $58.9(17.6)$ & 0.0012 & 61.4 & $54.0^{* *}$ & $63.5^{* *}$ & 57.4 \\
\hline Arterial pH & $7.42(0.03)$ & 0.64 & 7.43 & 7.42 & 7.42 & 7.42 \\
\hline $\mathrm{PaO} 2, \mathrm{mmHg}$ & $64.8(10.8)$ & 0.048 & 64.2 & $67.0^{*}$ & 64.3 & $62.1^{*}$ \\
\hline $\mathrm{PaCO} 2, \mathrm{mmHg}$ & $42.5(5.62)$ & $1.00 \times 10^{-4}$ & 42.0 & $40.8^{* *}$ & $44.3^{* *}$ & 43.7 \\
\hline Exacerbations in year prior to randomization ${ }^{\dagger}$ & $0(0-4)$ & 0.058 & 0 & $0^{* *}$ & 0 & 0 \\
\hline Exacerbations/year (over 3.3 years) & $0.16(0-3.12)$ & 0.054 & 0.19 & $0.00^{* *}$ & 0.19 & 0.15 \\
\hline \multicolumn{7}{|l|}{$\mathrm{rs} 1800470$ TGFB1 $^{\ddagger}$} \\
\hline $\mathrm{AA}$ & $36 \%$ & 0.04 & $24 \% * *$ & $42 \%$ & $34 \%$ & $45 \%$ \\
\hline$A G$ & $50 \%$ & & $51 \%$ ** & $46 \%$ & $55 \%$ & $57 \%$ \\
\hline GG & $14 \%$ & & $25 \% * *$ & $12 \%$ & $12 \%$ & $8 \%$ \\
\hline
\end{tabular}

Baseline values are for the entire cohort given as mean (sd) unless noted. $\mathrm{P}$ values represent tests for groupwise differences between the clusters (see text); values for the clusters represent mean or medians within the cluster. All 31 phenotypic characteristics used for clustering are shown; those not significant at $\mathrm{P}<0.05$ are displayed in italics. Genotype frequencies are given for the nominally significant association between rs 1800470 and cluster assignments.

${ }^{*} \mathrm{P}<0.05,{ }^{* *} \mathrm{P}<0.01$ in pairwise comparisons of cluster versus remainder of sample.

$\dagger$ Median (range)

₹ Values given as genotype frequency 
asthma subtypes[31]. These techniques show promise in identifying disease subtypes (subsets of subjects), or intermediate disease-related phenotypic characteristics (endotypes/endophenotypes[38]). Endophenotypes have already been of substantial utility in genetic association studies in psychiatry[39].

To date, however, there has been limited use of disease subtypes in genetic association studies in COPD. Investigators have tested for specific associations with classic subtypes $[11,40,41]$, or with specific diseaserelated phenotypic characteristics such as emphysema distribution[22] or functional measures[42]. Factor analysis has been used to demonstrate differences in heritability of components of asthma[43]. Cluster analysis is frequently used in gene expression, and such analyses have been used to define subtypes - though these subtypes have not always been clearly associated with the available clinical characteristics[44]. Our study demonstrates the potential utility of statistical learning methods in the heterogeneous syndrome of COPD.

Our cluster analyses identified four subtypes of subjects in this cohort with severe emphysema: 1) emphysema predominant, 2) milder severity, bronchodilatorresponsive, 3) discordant lung function/CT emphysema and airway severity, and 4) airway predominant. Some of the phenotypic associations in these groups, such as a lower BMI with more severe quantitative CT emphysema, have been previously seen $[13,45]$, while others, such as a higher bronchodilator responsiveness in the group with higher $\mathrm{FEV}_{1}$, differ from previous reports $[46,47]$. The association of the nonsynonymous Leu10Pro TGFB1 SNP rs1800470 with cluster 1 is consistent with a previously reported association of apical emphysema in this cohort [22] and association of this SNP with reduced lung function has also been seen in a Japanese emphysema cohort[48]. Notably, this SNP has been demonstrated to be of functional significance, with the $G$ allele ( $C$ on the reverse strand) resulting in increased production of TGFB1[49]. Several studies have demonstrated an increase in TGFB1 both in the lung[50-52] and in plasma[53] in subjects with COPD, as well as a relationship between TGFB1 levels and lung function, though the relationship between these findings and the rs1800470 genotype is not entirely clear[53].

Conversely, most of the previously reported SNP associations with COPD-related phenotypic characteristics did not demonstrate associations with our clusters. Nonsignificant findings could be due to loss of power from categorical cluster assignment and resulting small sample size, and the use of an omnibus test for genetic association. More importantly, our analysis attempts to determine whether genetic variants lead to a subtype of COPD subjects which share a set of phenotypic characteristics; as such, it does not attempt to determine the specific genotypic-phenotypic variables whose relationship leads to a significant association. Whether one of these approaches - association analysis with individual phenotypic characteristics, or with subtypes of subjectsis superior in identifying replicated genetic associations, or whether the approaches are separately informative, remains to be seen.

Our study has several strengths. First, we used relatively unbiased methods, in both factor analysis and cluster analysis, to select uncorrelated variables and determine severe COPD subtypes using the rich set of phenotypic and quantitative measures available in NETT. Second, our analysis is the largest reported cluster analysis using CT phenotypic variables. Third, despite our homogeneous study population, we were able to discern emphysema subtypes, which differed on variables not used to perform clustering. While all four of these subtypes have not previously been identified, our emphysema and airway-predominant clusters are consistent with a priori defined subtypes used in previous studies[13]. Importantly, recent evidence shows that airway wall thickening and emphysema aggregate independently in families of individuals with COPD [54], suggesting that recognizing these differences may be important for discovering genetic associations.

Our results should be regarded as exploratory for several reasons. First, our dataset was based on available NETT data. Specific relationships between variables for example, the high correlation between apical and total emphysema - may be due to selection biases of the NETT population. NETT subjects were likely biased towards those without predominant airway disease, and CT scans were suboptimal for assessment of airway wall remodeling due to the thicker slices associated with preMDCT (multi-detector CT) imaging. Similarly, our genotypic data was limited to a pre-specified subset of previous positive associations in candidate genes, and our cohort was limited to those enrolled in the NETT Genetics Ancillary Study (Additional File 1, Table S1). Our selection of phenotypic and genotypic variables for inclusion was strongly influenced by the limitations of available data, and decisions were made based on clinical judgement of relevance.

Second, our analysis also found that the separation of clusters was weak, indicating segmentation and not a true separation of these subtypes using clustering. Correspondingly, we found no strong evidence of smaller groups of more distinct subtypes. Furthermore, the small size of our clusters limits the power of association analysis, and our association with rs1800470 was not corrected for multiple comparisons. Given these limitations in this relatively homogeneous cohort, an attempt to validate these findings of specific subtypes using these or similar methods in other well-phenotyped 
COPD cohorts should be performed. Using a more heterogeneous and less selected group of subjects, in combination with improved radiographic measures, may result in more pronounced and distinct subpopulations.

\section{Conclusions}

The volume of genetic and phenotypic information available in COPD cohorts is rapidly increasing; the number of potential relationships between phenotypic and genotypic characteristics increases exponentially. Statistical learning techniques using multivariate methods, such as dimension reduction and cluster analysis, have the potential to assist in analyses of these complicated problems. Our study demonstrates that application of these techniques, even in a highly selected group of subjects with severe emphysema, has the potential to elucidate phenotypic heterogeneity and disease pathophysiology.

Additional file 1: Supplementary Information. Supplemental Methods, Results, and Figures.

Click here for file

[http://www.biomedcentral.com/content/supplementary/1465-9921-1130-S1.DOC]

\section{Acknowledgements}

This work was supported by U.S. National Institutes of Health [Grants T32HL007427, K12HL089990, R01HL075478, R01HL084323, and P01 HL083069]. The National Emphysema Treatment Trial was supported by contracts with the National Heart, Lung, and Blood Institute [N01HR76101N01HR76116, N01HR76118, N01HR76119], the Centers for Medicare and Medicaid Services, and the Agency for Healthcare Research and Quality This article is based on research that is funded in part by grants from the National Institutes of Health $(\mathrm{NIH})$ and is therefore subject to the mandatory $\mathrm{NIH}$ Public Access Policy.

Co-investigators in the NETT Genetics Ancillary Study include Joshua Benditt, Gerard Criner, Malcolm DeCamp, Philip Diaz, Mark Ginsburg, Larry Kaiser, Marcia Katz, Mark Krasna, Neil MacIntyre, Barry Make, Rob McKenna, Fernando Martinez, Zab Mosenifar, John Reilly, Andrew Ries, Frank Sciurba, and James Utz.

The study sponsors of the NETT Genetics Ancillary Study had no role in study design, data collection, analysis and interpretation, manuscript preparation, or submission for publication.

\section{Author details}

${ }^{1}$ Channing Laboratory, Brigham \& Women's Hospital, Boston, MA, USA. 2Division of Pulmonary and Critical Care Medicine, Brigham \& Women's Hospital, Boston, MA, USA. ${ }^{3}$ Department of Biostatistics, Harvard School of Public Health, Boston, MA, USA. ${ }^{4}$ Division of Pulmonary and Critical Care, Temple University School of Medicine, Philadelphia, PA, USA. ${ }^{5}$ Department of Radiology, Carver College of Medicine, University of lowa, lowa City, IA, USA. ${ }^{6}$ Division of Pulmonary and Critical Care Medicine, University of Michigan Health System, Ann Arbor, MI, USA. 'University of Pittsburgh Medical Center, Pittsburgh, PA, USA.

\section{Authors' contributions}

MHC carried out the data analysis and drafted the manuscript. EKS conceived and designed the study, and assisted in data analysis and interpretation. GRW and EAH generated the $\mathrm{CT}$ data. $\mathrm{TH}$ and $\mathrm{NL}$ assisted in the statistical analysis. GJC, EAH, and FJM participated in generating the data and in data analysis. JJR helped design the study and assisted in data analysis. All authors read, helped revise, and approved the final manuscript.

\section{Competing interests}

GJC has received investigational grants from Emphysis Medical Inc, Aeris Therapeutics, Boehringer Ingelheim, Astra Zeneca, GlaxoSmithKline, Forest Pharmaceuticals, and Schering-Plough. EAH is a founder and shareholder of VIDA Diagnostics, Inc. (Coralville, lowa). EKS has received honoraria from GlaxoSmithKine, Wyeth, Bayer, and Astra-Zeneca, consulting fees from GlaxoSmithKline and Astra-Zeneca, and grant support from GlaxoSmithKline.

Received: 9 September 2009 Accepted: 16 March 2010 Published: 16 March 2010

\section{References}

1. Pauwels RA, Buist AS, Calverley PM, Jenkins CR, Hurd SS: Global strategy for the diagnosis, management, and prevention of chronic obstructive pulmonary disease. NHLBI/WHO Global Initiative for Chronic Obstructive Lung Disease (GOLD) Workshop summary. Am J Respir Crit Care Med 2001, 163(5):1256-1276

2. Calverley PM: The GOLD classification has advanced understanding of COPD. Am J Respir Crit Care Med 2004, 170(3):211-212, discussion 214.

3. Hersh CP, Jacobson FL, Gill R, Silverman EK: Computed tomography phenotypes in severe, early-onset chronic obstructive pulmonary disease. COPD 2007, 4(4):331-337.

4. Rennard SI, Vestbo J: The many "small COPDs": COPD should be an orphan disease. Chest 2008, 134(3):623-627.

5. Wedzicha JA: The heterogeneity of chronic obstructive pulmonary disease. Thorax 2000, 55(8):631-632.

6. Reilly JJ: COPD and declining FEV1-time to divide and conquer? N Engl $J$ Med 2008, 359(15):1616-1618.

7. Pistolesi M: Beyond airflow limitation: another look at COPD. Thorax 2009, 64(1):2-4.

8. Ioannidis JP, Ntzani EE, Trikalinos TA, Contopoulos-loannidis DG: Replication validity of genetic association studies. Nat Genet 2001, 29(3):306-309.

9. Hersh $\mathrm{CP}$, Demeo DL, Lange C, Litonjua AA, Reilly JJ, Kwiatkowski D, Laird N, Sylvia JS, Sparrow D, Speizer FE, et al: Attempted replication of reported chronic obstructive pulmonary disease candidate gene associations. Am J Respir Cell Mol Biol 2005, 33(1):71-78.

10. Ioannidis JP, Boffetta P, Little J, O'Brien TR, Uitterlinden AG, Vineis $P$, Balding DJ, Chokkalingam A, Dolan SM, Flanders WD, et al: Assessment of cumulative evidence on genetic associations: interim guidelines. Int $J$ Epidemiol 2008, 37(1):120-132.

11. Baranova $H$, Perriot J, Albuisson E, Ivaschenko T, Baranov VS, Hemery B, Mouraire P, Riol N, Malet P: Peculiarities of the GSTM1 0/0 genotype in French heavy smokers with various types of chronic bronchitis. Hum Genet 1997, 99(6):822-826.

12. Sandford AJ, Chagani T, Weir TD, Connett JE, Anthonisen NR, Pare PD: Susceptibility genes for rapid decline of lung function in the Lung Health Study. Am J Respir Crit Care Med 2001, 163(2):469-473.

13. Ogawa E, Nakano Y, Ohara T, Muro S, Hirai T, Sato S, Sakai H, Tsukino M, Kinose $D$, Nishioka $M$, et al: Body mass index in male patients with COPD: correlation with low attenuation areas on CT. Thorax 2009, 64(1):20-25.

14. Hastie T, Tibshirani $\mathrm{R}$, Friedman $\mathrm{JH}$ : The elements of statistical learning: data mining, inference, and prediction. New York: Springer 2001.

15. Pistolesi M, Camiciottoli G, Paoletti M, Marmai C, Lavorini F, Meoni E, Marchesi C, Giuntini C: Identification of a predominant COPD phenotype in clinical practice. Respir Med 2008, 102(3):367-376.

16. Wardlaw AJ, Silverman M, Siva R, Pavord ID, Green R: Multi-dimensional phenotyping: towards a new taxonomy for airway disease. Clin Exp Allergy 2005, 35(10):1254-1262.

17. Thabut G, Dauriat G, Stern JB, Logeart D, Levy A, Marrash-Chahla R, Mal H: Pulmonary hemodynamics in advanced COPD candidates for lung volume reduction surgery or lung transplantation. Chest 2005, 127(5):1531-1536.

18. Weatherall M, Travers J, Shirtcliffe PM, Marsh SE, Williams MV, Nowitz MR, Aldington $S$, Beasley R: Distinct clinical phenotypes of airways disease defined by cluster analysis. Eur Respir J 2009, 34(4):812-8.

19. Paoletti M, Camiciottoli G, Meoni E, Bigazzi F, Cestelli L, Pistolesi M, Marchesi C: Explorative data analysis techniques and unsupervised clustering methods to support clinical assessment of Chronic Obstructive Pulmonary Disease (COPD) phenotypes. I Biomed Inform 2009, 42(6):1013-21. 
20. Roy K, Smith J, Kolsum U, Borrill Z, Vestbo J, Singh D: COPD phenotype description using principal components analysis. Respir Res 2009, 10:41.

21. Fishman A, Martinez F, Naunheim K, Piantadosi S, Wise R, Ries A, Weinmann G, Wood DE: A randomized trial comparing lung-volumereduction surgery with medical therapy for severe emphysema. $N$ Engl J Med 2003, 348(21):2059-2073

22. DeMeo DL, Hersh CP, Hoffman EA, Litonjua AA, Lazarus R, Sparrow D, Benditt JO, Criner G, Make B, Martinez FJ, et al: Genetic determinants of emphysema distribution in the National Emphysema Treatment Trial. Am J Respir Crit Care Med 2007, 176(1):42-48

23. Foreman MG, DeMeo DL, Hersh CP, Carey VJ, Fan VS, Reilly JJ, Shapiro SD, Silverman EK: Polymorphic variation in surfactant protein $B$ is associated with COPD exacerbations. Eur Respir J 2008, 32(4):938-944

24. Washko GR, Criner GJ, Mohsenifar Z, Sciurba FC, Sharafkhaneh A, Make BJ, Hoffman EA, Reilly JJ: Computed tomographic-based quantification of emphysema and correlation to pulmonary function and mechanics. COPD 2008, 5(3):177-186

25. Kim WJ, Silverman EK, Hoffman E, Criner GJ, Mosenifar Z, Sciurba FC, Make BJ, Carey V, Estepar RS, Diaz A, et al: CT metrics of airway disease and emphysema in severe COPD. Chest 2009, 136(2):396-404.

26. Silverman EK: Progress in chronic obstructive pulmonary disease genetics. Proc Am Thorac Soc 2006, 3(5):405-408

27. DeMeo DL, Mariani TJ, Lange C, Srisuma S, Litonjua AA, Celedon JC, Lake SL, Reilly JJ, Chapman HA, et al: The SERPINE2 gene is associated with Chronic Obstructive Pulmonary Disease. Am J Hum Genet 2006, 78(2):253-64

28. Zhu G, Warren L, Aponte J, Gulsvik A, Bakke P, Anderson WH, Lomas DA, Silverman EK, Pillai SG: The SERPINE2 gene is associated with chronic obstructive pulmonary disease in two large populations. Am J Respir Crit Care Med 2007, 176(2):167-173

29. de Bakker PI, Yelensky R, Pe'er I, Gabriel SB, Daly MJ, Altshuler D: Efficiency and power in genetic association studies. Nat Genet 2005 37(11):1217-1223.

30. Barrett JC, Fry B, Maller J, Daly MJ: Haploview: analysis and visualization of LD and haplotype maps. Bioinformatics 2005, 21(2):263-265.

31. Haldar P, Pavord ID, Shaw DE, Berry MA, Thomas M, Brightling CE, Wardlaw AJ, Green RH: Cluster analysis and clinical asthma phenotypes. Am J Respir Crit Care Med 2008, 178(3):218-224.

32. Burrows B, Fletcher CM, Heard BE, Jones NL, Wootliff JS: The emphysematous and bronchial types of chronic airways obstruction. A clinicopathological study of patients in London and Chicago. Lancet 1966, 1(7442):830-835

33. Celli BR: Roger S. Mitchell lecture. Chronic obstructive pulmonary disease phenotypes and their clinical relevance. Proc Am Thorac Soc 2006, 3(6):461-465

34. Friedlander AL, Lynch D, Dyar LA, Bowler RP: Phenotypes of chronic obstructive pulmonary disease. COPD 2007, 4(4):355-384.

35. Taube C, Lehnigk B, Paasch K, Kirsten DK, Jorres RA, Magnussen H: Factor analysis of changes in dyspnea and lung function parameters after bronchodilation in chronic obstructive pulmonary disease. Am J Respir Crit Care Med 2000, 162(1):216-220.

36. Hajiro T, Nishimura K, Tsukino M, Ikeda A, Koyama H, Izumi T: Analysis of clinical methods used to evaluate dyspnea in patients with chronic obstructive pulmonary disease. Am J Respir Crit Care Med 1998, 158(4):1185-1189.

37. Lapperre TS, Snoeck-Stroband JB, Gosman MM, Stolk J, Sont JK, Jansen DF, Kerstjens HA, Postma DS, Sterk PJ: Dissociation of lung function and airway inflammation in chronic obstructive pulmonary disease. Am J Respir Crit Care Med 2004, 170(5):499-504.

38. Anderson GP: Endotyping asthma: new insights into key pathogenic mechanisms in a complex, heterogeneous disease. Lancet 2008 372(9643):1107-1119.

39. Burmeister M, Mclnnis MG, Zollner S: Psychiatric genetics: progress amid controversy. Nat Rev Genet 2008, 9(7):527-540.

40. Ito I, Nagai S, Hoshino Y, Muro S, Hirai T, Tsukino M, Mishima M: Risk and severity of COPD is associated with the group-specific component of serum globulin 1F allele. Chest 2004, 125(1):63-70.

41. Sakao S, Tatsumi K, Igari H, Watanabe R, Shino $Y$, Shirasawa H, Kuriyama T: Association of tumor necrosis factor-alpha gene promoter polymorphism with low attenuation areas on high-resolution $\mathrm{CT}$ in patients with COPD. Chest 2002, 122(2):416-420.

42. Hersh CP, Demeo DL, Lazarus R, Celedon JC, Raby BA, Benditt JO, Criner G, Make B, Martinez FJ, Scanlon PD, et al: Genetic association analysis of functional impairment in chronic obstructive pulmonary disease. Am J Respir Crit Care Med 2006, 173(9):977-984.

43. Pillai SG, Tang Y, Oord van den E, Klotsman M, Barnes K, Carlsen K, Gerritsen J, Lenney W, Silverman M, Sly P, et al: Factor analysis in the Genetics of Asthma International Network family study identifies five major quantitative asthma phenotypes. Clin Exp Allergy 2008, 38(3):421-429.

44. Spira A, Beane J, Pinto-Plata V, Kadar A, Liu G, Shah V, Celli B, Brody JS: Gene expression profiling of human lung tissue from smokers with severe emphysema. Am J Respir Cell Mol Biol 2004, 31(6):601-610.

45. Lee YK, Oh YM, Lee JH, Kim EK, Kim N, Seo JB, Lee SD: Quantitative assessment of emphysema, air trapping, and airway thickening on computed tomography. Lung 2008, 186(3):157-165.

46. Makita $H$, Nasuhara $Y$, Nagai $K$, Ito $Y$, Hasegawa M, Betsuyaku T, Onodera $Y$, Hizawa N, Nishimura M: Characterisation of phenotypes based on severity of emphysema in chronic obstructive pulmonary disease. Thorax 2007, 62(11):932-937.

47. Calverley P, Pauwels R, Vestbo J, Jones P, Pride N, Gulsvik A, Anderson J, Maden C: Combined salmeterol and fluticasone in the treatment of chronic obstructive pulmonary disease: a randomised controlled trial. Lancet 2003, 361(9356):449-456.

48. Ito M, Hanaoka M, Droma Y, Hatayama O, Sato E, Katsuyama Y, Fujimoto K, Ota M: The association of transforming growth factor beta 1 gene polymorphisms with the emphysema phenotype of COPD in Japanese. Intern Med 2008, 47(15):1387-1394.

49. Suthanthiran M, Li B, Song JO, Ding R, Sharma VK, Schwartz JE, August P: Transforming growth factor-beta 1 hyperexpression in African-American hypertensives: A novel mediator of hypertension and/or target organ damage. Proc Natl Acad Sci USA 2000, 97(7):3479-3484

50. de Boer WI, van Schadewijk A, Sont JK, Sharma HS, Stolk J, Hiemstra PS, van Krieken JH: Transforming growth factor beta1 and recruitment of macrophages and mast cells in airways in chronic obstructive pulmonary disease. Am J Respir Crit Care Med 1998, 158(6):1951-1957.

51. Takizawa H, Tanaka M, Takami K, Ohtoshi T, Ito K, Satoh M, Okada Y, Yamasawa F, Nakahara K, Umeda A: Increased expression of transforming growth factor-beta1 in small airway epithelium from tobacco smokers and patients with chronic obstructive pulmonary disease (COPD). Am J Respir Crit Care Med 2001, 163(6):1476-1483.

52. Vignola AM, Chanez P, Chiappara G, Merendino A, Pace E, Rizzo A, la Rocca AM, Bellia V, Bonsignore G, Bousquet J: Transforming growth factorbeta expression in mucosal biopsies in asthma and chronic bronchitis. Am J Respir Crit Care Med 1997, 156(2 Pt 1):591-599.

53. Mak JC, Chan-Yeung MM, Ho SP, Chan KS, Choo K, Yee KS, Chau CH, Cheung AH, Ip MS: Elevated plasma TGF-beta1 levels in patients with chronic obstructive pulmonary disease. Respir Med 2009, 103(7):1083-1089.

54. Patel BD, Coxson HO, Pillai SG, Agusti AG, Calverley PM, Donner CF, Make BJ, Muller NL, Rennard SI, Vestbo J, et al: Airway wall thickening and emphysema show independent familial aggregation in chronic obstructive pulmonary disease. Am J Respir Crit Care Med 2008, 178(5):500-505.

55. Brogger J, Steen VM, Eiken HG, Gulsvik A, Bakke P: Genetic association between COPD and polymorphisms in TNF, ADRB2 and EPHX1. Eur Respir J 2006, 27(4):682-688.

56. Hersh CP, DeMeo DL, Reilly JJ, Silverman EK: Xenobiotic metabolizing enzyme gene polymorphisms predict response to lung volume reduction surgery. Respir Res 2007, 8:59.

57. He JQ, Connett JE, Anthonisen NR, Pare PD, Sandford AJ: Glutathione S transferase variants and their interaction with smoking on lung function. Am J Respir Crit Care Med 2004, 170(4):388-394.

58. Guo X, Lin HM, Lin Z, Montano M, Sansores R, Wang G, DiAngelo S, Pardo A, Selman M, Floros J: Surfactant protein gene A, B, and D marker alleles in chronic obstructive pulmonary disease of a Mexican population. Eur Respir J 2001, 18(3):482-490.

59. Celedon JC, Lange C, Raby BA, Litonjua AA, Palmer L, DeMeo DL, Reilly رل Kwiatkowski DJ, Chapman HA, Laird N, et al: The transforming growth 
factor-beta1 (TGFB1) gene is associated with chronic obstructive pulmonary disease (COPD). Hum Mol Genet 2004, 13(15):1649-1656.

60. Wu L, Chau J, Young RP, Pokorny V, Mills GD, Hopkins R, McLean L, Black PN: Transforming growth factor-beta1 genotype and susceptibility to chronic obstructive pulmonary disease. Thorax 2004, 59(2):126-129.

61. Castaldi PJ, Cho MH, Cohn M, Langerman F, Moran S, Tarragona N, Moukhachen H, Venugopal R, Hasimja D, Kao E, et al: The COPD genetic association compendium: a comprehensive online database of COPD genetic associations. Hum Mol Genet 2009, 19(3):526-34.

doi:10.1186/1465-9921-11-30

Cite this article as: Cho et al.: Cluster analysis in severe emphysema

subjects using phenotype and genotype data: an exploratory

investigation. Respiratory Research 2010 11:30.

Submit your next manuscript to BioMed Central and take full advantage of:

- Convenient online submission

- Thorough peer review

- No space constraints or color figure charges

- Immediate publication on acceptance

- Inclusion in PubMed, CAS, Scopus and Google Scholar

- Research which is freely available for redistribution

Submit your manuscript at www.biomedcentral.com/submit 